\title{
ANALYSIS OF NILE CROCODILE (CROCODYLUS NILOTICA) HUNTING IN SELECTED COMMUNITIES AROUND FRESH WATER AND SALT WATER TRANSITIONAL AREAS OF RIVERS STATE, NIGERIA
}

\author{
*Ijeomah HM and Efenakpo OD \\ Department of Forestry and Wildlife Management, University of Port Harcourt, PMB5323, Port Harcourt, \\ Rivers State, Nigeria
}

Accepted : 21 September 2011

\begin{abstract}
Nile crocodile (Crocodylus nilotica) is threatened and the rate of its hunting and the vulnerability ranking of the species on basis of size or age is unknown in Nigeria, particularly in coastal areas. Analysis of $C$. nilotica hunting was therefore conducted in Choba, Aluu, Abonema and Emohua, being communities located around the fresh water / saltwater transitional river, with the aim of determining the most vulnerable stage of the species in the study area. The study was conducted from January 2008 to December 2010. Structured questionnaires, field observations and in - depth interviews were used for the study. Through the chairman of fishermen / hunters association all fishermen and hunters operating in selected communities who had ever caught crocodile were identified and catches of $C$. nilotica were monitored on monthly basis throughout the period of study. A set of questionnaire were administered to all the fishermen/hunters in the study area. In all, a total of 70 fishermen/hunter respondents were interviewed to confirm data obtained between 2008 and 2010. Data obtained were analysed using descriptive statistics in form of frequency, percentages, means, pie chart, bar chart and graph. Results revealed that a total of 3206 crocodiles were caught by 70 fishermen in the study area between 2008 and 2010. The rate of hunting was higher in Abonema and Emohua within the studied period. Mean monthly catches in 2008, 2009 and 2010 were 33, 37 and 33 respectively for Abonema. Numbers of catches decreased progressively between 2008 and 2010 in Abonema and Choba. The juveniles were more vulnerable to be caught in the study area than sub adults and adults, and were mostly caught during dry season $(83 \%)$ by chance $(61 \%)$ through entanglements in fishing nets as they stray out to feed. About $54.6 \%$ of fishermen and hunters mostly caught juveniles, $32.6 \%$ mostly caught sub adults while only $12.8 \%$ mostly caught adults. Fishermen find the adults difficult to handle because they can tear fishing nets. The juveniles were mostly caught by fishermen as hunters normally set traps at strategic locations for adults. Catches were mainly for consumption. Unregulated exploitation of juveniles from the study area will drastically reduce population of the species as there is no legislation regulating hunting of crocodile at any stage. With time it will be difficult for an adult $\boldsymbol{C}$. nilotica to be found in the study area and breeding will stop when existing adults die without replacement as the juveniles could not be allowed to survive to adult stage.
\end{abstract}

Key words: Wildlife conservation, Crocodile exploitation, Rural households, Endangered species, Nigeria

\section{INTRODUCTION}

One of the most serious global challenges is the sustained utilization of limited natural resources in the face of ever increasing human population. This is worse for countries like Nigeria with high rates of poverty, where the governments are nonresponsive to the needs of the people, and the majority of the people heavily rely on natural resources for survival (Ijeomah 2007; Ijeomah and Emelue 2009). Man has been the greatest threat to natural resources or wildlife conservation as Ogogo (2008) has emphasised that 'Except under the most extenuating circumstances, no predator except man is

*Corresponding author : henryijeomah@yahoo.com capable of exterminating a prey species". Human's activities that have posed extinction threats to wildlife species includes; habitat destruction, environmental pollution, poaching and heavy hunting, and among all human's activities listed above heavy hunting ranked as one of the greatest threats to Nile crocodile (Fergusson 2010).

More than 750 surveys using variety of methods have been carried out on Crocodylus niloticus (Nile crocodile) since 1950s. Despite covering 315 different locations only 8 of these have been surveyed enough to allow estimation of population trends (Lainez 2009). All of the- 
se are located in southern and East Africa where there have been significant recent improvements in species monitoring. In Central and West Africa the availability of survey data is very poor. Overall survey data are insufficient or nonexistent in 25 of 42 Range States (Fergusson 2010). More recently, Bishop et al. (2009) discovered the reduced effective population size in the overexploited Okavango Delta population in Botswana. Similar challenge may be experienced in other non surveyed areas as the inhabitants of many areas in Sub Saharan Africa have always perceived hunting as a means of livelihood. Among this numerous work carried out on Nile crocodiles a great deal of field based work are not from West Africa as other researchers have rightly reviewed that the few works that exist in West Africa and Central Africa are mostly in the form of anecdotal reports (Broadley et al. 2004; Lainez 2009). And this has raised the concern of many groups, bodies and agencies such as Crocodile Specialist Group (CSG) to prioritise research on crocodile from West and central African region (Fergusson 2010).

In order to embark on conservation programmes that will be efficient, effective and sustainable within a locality, especially in Rivers State of Niger Delta of Nigeria; where every species is under regular threat of environmental pollution; frequent youth restiveness due to perceived government negligence, high rate of rural poverty and joblessness information on the rate of $C$. niloticus depletion is therefore very essential

This paper therefore assesses the rate at which C. niloticus are exploited in Rivers State; investigates the most vulnerable size of crocodiles hunted in the study area.

\section{MATERIAL AND METHOD}

Study Area: The areas selected for the study are all in Rivers State Nigeria, Choba is a town located in Obio/Akpor Local Government Area which lies between latitude $04^{0} 3^{11}$ to $5^{0} 00 \mathrm{~N}$ and longitude $06^{0} 45^{1}$ and $07^{0} 00 \mathrm{E}$ (Nwankwo et al 2010). Emohua is the headquarters of Emohua Local Government Area and lies on latitude $04^{0} 75^{1} \mathrm{~N}$ and longitude $07^{0} 11^{\prime \prime} \mathrm{E}$ (GPS). Aluu is a community in Ikwerre Local Government Area and lies between latitude 0
$4^{0} 65^{1} \mathrm{~N}$ and longitude $05^{0}$ to $07^{0} 12^{11} \mathrm{E}$ (GPS). Abonema is a community in Akuku Toru Local Government Area and lies on Latitude $04^{\circ} 44^{\prime}$ $0^{\prime \prime}$ North and longitude $06^{\circ} 46^{\prime} 18^{\prime \prime}$ East (GPS). Farming is the major occupation in Choba, Aluu and Emohua unlike Abonema were fishing is the major occupation of households (Fig $1)$.

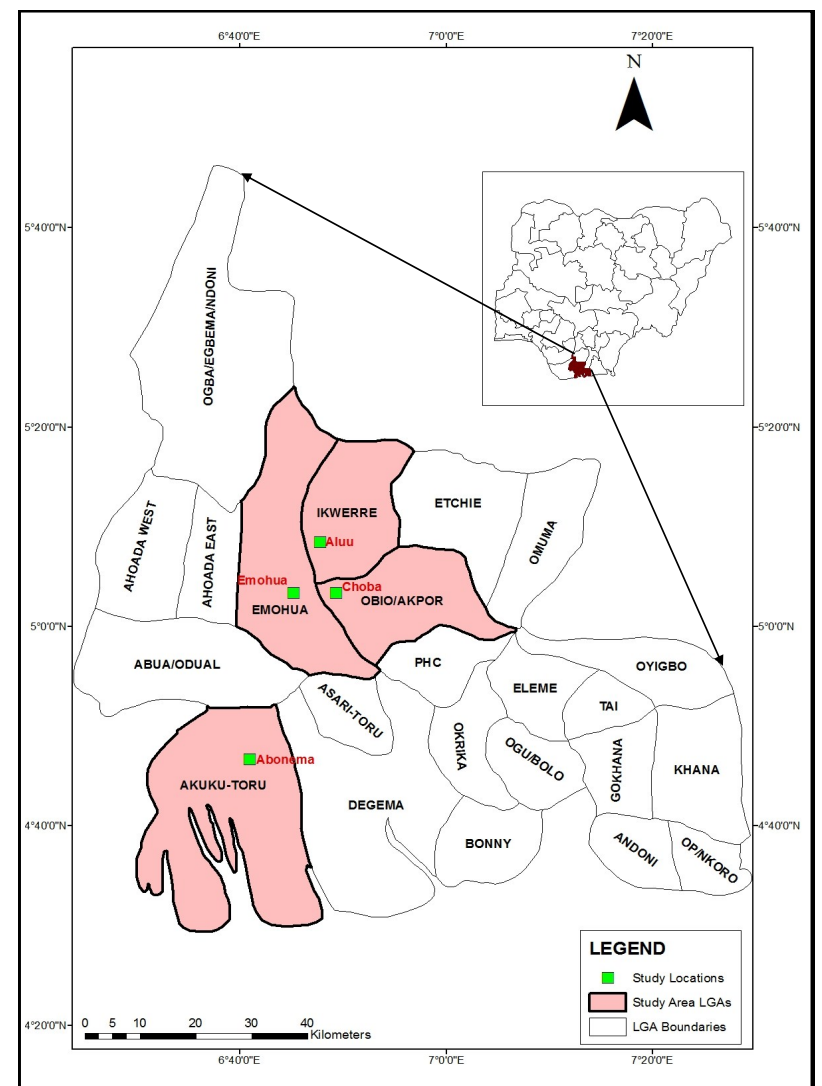

Fig 1: Map of Rivers Satate showing the Study Locations and Study Areaa LGAs

\section{Sampling Techniques}

The study locations where selected based on their closeness to the freshwater/salt water transitional river. The selected communities are: Choba, Aluu, Emohua and Abonema of Rivers State as shown in the map above. Data for the study were obtained through pre-tested structured questionnaires, in-depth interviews and field observations. Through the chairman of fishermen/ hunters association all hunters and fishermen (70) who had caught at least one crocodile in the study area were identified and catches were monitored from January 2008 to December 2010. A set of pre-tested structured questionnaires were administered to all fishermen/hunters who had ever caught a crocodile. In all, 70 fishermen/hunters were interviewed from a population of 318 fishermen / 
hunters.

The numbers of questionnaires distributed for different categories of respondents in each selected site is shown below in Table.1:

Table 1: Number of respondents in selected communities

\begin{tabular}{lllll}
\hline Abonema & Aluu & Choba & Emohua & Total \\
\hline 23 & 12 & 12 & 23 & 70
\end{tabular}

\section{Data Collection}

The methods used for the collection of data for the research work were basically in three ways; pre- tested structured questionnaires, field observation, and personal interviews depending on the objective to be achieved. Classification of crocodile by Hutton (1989) and Wikipedia (2007) into various sizes as juvenile $\leq 1.2 \mathrm{~m}$ ( $<$ three years), sub-adult $>1.2 \mathrm{~m}$ band $<4 \mathrm{~m}$ $(<$ ten years) and adult $>4$ and $\geq 8 \mathrm{~m}(11-100$ years) was adopted.

\section{Data Analysis}

Data obtained from the study were analysed using descriptive statistic in form of counts of frequency, bar chart and Pie chart. Total numbers of catches for each year was gotten from the addition of all catches made by fishermen/ hunters in each year. Rate of hunting in selected communities on monthly basis where arrived at by dividing total numbers of catches in a year (annual) by 12 months. The average numbers of crocodile caught by fishermen/ hunters in each community were calculated by dividing the numbers of total catches with the numbers of fishermen/hunters in that community.

\section{RESULTS}

\section{Hunting Rate of Nile Crocodiles}

The total numbers of crocodile caught among fishermen / hunters sampled in Abonema and Choba communities decreased progressively from 2008 to 2010 unlike in Aluu and Emohua communities were the catches in 2009 exceeded those of 2008. The catches recorded in 2010 were the lowest in the four communities studied (Fig 2). Emohua community recorded the highest numbers of catches (31\%) from 2008 to 2010 (Table 2).

The mean annual number of crocodile catches per person was highest in Choba in both 2008 (26) and 2010 (20). However, in 2009, the catches per person were highest in Aluu community. Each fisherman/hunter respondent in Aluu caught 29 crocodile.

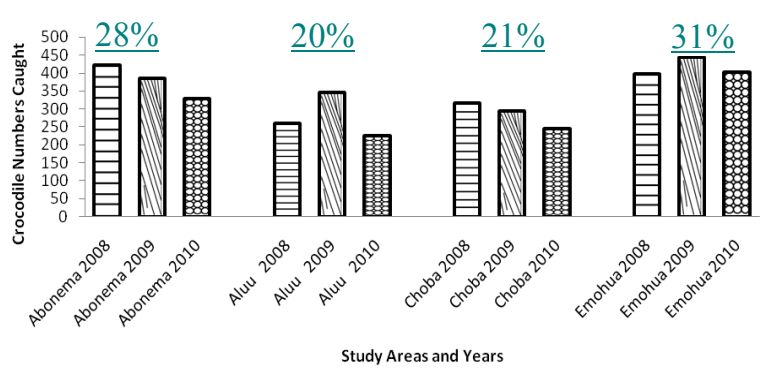

Figure2: Number of crocodiles hunted in each community from 2008 - 2010 by respondents (Percentage values given above)

Table 2: Mean monthly catches of crocodiles and averge number of Crocodile caught by fisherman/ hunters (Annual basis)

\begin{tabular}{lllll}
\hline Year & Abonema & Aluu & Choba & Emohua \\
\hline 2008 & $35(18)$ & $22(22)$ & $26(26)$ & $33(17)$ \\
2009 & $32(17)$ & $29(29)$ & $25(25)$ & $37(19)$ \\
2010 & $27(14)$ & $19(19)$ & $20(20)$ & $33(17)$ \\
\hline
\end{tabular}

Vulnerable Size (Stage) of Crocodile for Hunting

Catching of crocodile in the study areas were not deliberate but mostly by chance. With the exception of Aluu where seasonal variation of catches is $50 \%$ for both dry and rainy season, the season for abundant catches in other communities was dry season (Table 5).

Table 3: Variation of crocodile catches according to season and catching strategy in study area

\begin{tabular}{|c|c|c|c|}
\hline Study area & Variation & Frequency & Percentage (\%) \\
\hline \multicolumn{4}{|l|}{ Abonema } \\
\hline \multirow[t]{2}{*}{ Season } & Rainy season & 14 & 17.3 \\
\hline & Dry season & 19 & 82.3 \\
\hline \multirow[t]{2}{*}{ Catching strategy } & Purposely set trap & 8 & 22.0 \\
\hline & By chance & 15 & 78.0 \\
\hline \multicolumn{4}{|l|}{ Aluu } \\
\hline \multirow[t]{2}{*}{ Season } & Rainy season & 6 & 50.0 \\
\hline & Dry season & 6 & 50.0 \\
\hline \multirow[t]{2}{*}{ Catching strategy } & Purposely set trap & 2 & 17.0 \\
\hline & By chance & 10 & 83.0 \\
\hline \multicolumn{4}{|l|}{ Choba } \\
\hline \multirow[t]{2}{*}{ Season } & Rainy season & 0 & 0 \\
\hline & Dry season & 12 & 100 \\
\hline \multirow[t]{2}{*}{ Catching strategy } & Purposely set trap & 2 & 17.0 \\
\hline & By chance & 10 & 83.0 \\
\hline \multicolumn{4}{|l|}{ Emohua } \\
\hline \multirow[t]{2}{*}{ Season } & Rainy season & 2 & 9.0 \\
\hline & Dry season & 21 & 91.0 \\
\hline \multirow[t]{2}{*}{ Catching strategy } & Purposely set trap & 15 & 65.0 \\
\hline & By chance & 8 & 35.0 \\
\hline \multicolumn{4}{|l|}{ Cumulative } \\
\hline Season & Rainy season & 12 & 17.0 \\
\hline \multirow[t]{3}{*}{ Catching strategy } & Dry season & 58 & 83.0 \\
\hline & Purposely set trap & 27 & 39.0 \\
\hline & By chance & 43 & 61.0 \\
\hline
\end{tabular}




\section{DISCUSSION}

A total of 3,206 crocodiles were caught in the study area between 2008 and 2010. The removal of 3,206 individuals of crocodile from a water body in a space of three years without any plan for replacement is a form of unsustainable utilization. The progressive decrease in the number of catches between 2008 and 2010 in Abonema and Choba can be attributed to the fact that the population of crocodile in the areas have decreased due to decimation pressure and habitat destruction. Bolton (1997) obtained a similar result that crocodile population crashed under the pressure of hunting largely because the process of hunting was removing the least expendable segment of the population. The numbers of catches in Aluu and Emohua communities were relatively highest in 2009 due to increased effort by the fishermen to catch more individuals as a result of poverty.

The total number of crocodiles caught between 2008 and 2010 was higher in Emohua and Abonema than Choba and Aluu communities (Fig 2). Not fewer than 33 and 27 individuals of crocodile were killed on monthly basis in Emohua and Abonema respectively (Table 2). This could be attributed to the fact that Abonema and Emohua have more fishermen/ hunters than Aluu and Choba communities (Table 1). It can also be related to the relatively larger water body in Abonema area which provides large surface area for fishermen/hunters to operate. The fact that the fishermen /hunters in Emohua community make sales outside their community and the resultant high demand pressure from buyers can stimulate them to increase their hunting effort because of the ready market.

The average numbers of crocodile caught by fishermen/hunters on annual basis were higher in Choba and Aluu compared to Abonema and Emohua between 2008 and 2010 (Table 2). This could be as a result of the relatively large operational area of each fishermen/hunters in Choba and Aluu as there are only 12 fisher$\mathrm{men} /$ hunters in each of the communities. The implication of this high hunting rate of crocodile is that as efforts are increased in each community there will be commensurate reduction in numbers of crocodiles in the wild. Crocodiles were mainly caught in the dry season which is when water tide or level is low. During this period most communities in riverrine areas in Rivers State always have them entangled in their fishing nets or baskets. Catches during rainy season is always low because of high water level similar to what is obtainable is fishing. Respondents who reported that most of their catches were during rainy season may have made those catches towards the transition period between rainy and dry season.

The crocodile sizes mostly caught by fishermen/hunters in the study area were the juvenile size. This could be attributed to the fact that it is less dangerous compared to other sizes and can also be related to the implements used in catching them. The juveniles were mostly caught with fishing nets or baskets. Majority of them got entrapped in fishing nets as juveniles stray away to feed. This agrees with the work of Hutton (1989) which elaborated on the variation in habitat utilization between juveniles, sub-adults and adults and reported that the juveniles enter a dispersal phase at approximately $1.2 \mathrm{~m}$ length and has a dual habitat as aquatic and terrestrial (Hutton 1989; Fergusson 2010). The fishermen/hunters that purposely set traps to catch the adults always have few catches when compared with the catches of juveniles made. However, catches of juveniles by fishermen is not deliberate but always by chance (Table 3). This partially agrees with Aust (2009) on Nile crocodile.

The most vulnerable stage of the crocodile in the study area was the juvenile stage because out of the 70 fishermen/hunters sampled in the study area 38 being $54.3 \%$ caught the juvenile mostly, followed by sub adults and adults. The high depletion of juveniles will seriously affect the population of sub adults and adults because it is only the few juveniles that are not caught will develop to sub-adults and adults and if development to adult stage is hampered breeding will also be affected because the breeding stock will one day be killed, die naturally or become too old to breed. Some of the fishermen/ hunters who caught these juveniles have been eating and selling them hence efforts are not made to stop the entanglement of the juveniles in fishing nets. This kind of high juvenile decimation confirmed the work of Jones (1991) that Nile crocodile is an endangered species that is at the verge of extinction in West Africa. 
The adults are not normally caught with fishing nets because they can tear the nets. Instead they are caught with traps and catching of the adults are not common as they are mostly caught by hunters and not fishermen.

\section{CONCLUSION}

Nile crocodiles are consistently hunted in the study area. The lachrymal hunting of Nile crocodile makes it difficult for replacement at the same rate of decimation and is seriously reducing their population. All age classes of crocodile in the study area is vulnerable to hunting. However, juveniles are the most vulnerable age class. The probability of a juvenile growing to adult size is very low because of the high mortality rate of the juveniles. This will likely lead to a progressive increase in the death of juveniles and sub adults as the replacement of an adult crocodile in the wild is bound to take several years and usually involve the production and loss of large number of hatchlings. Even though killing of the species at juvenile stage has not been intentional but efforts were not made to restrict the fishermen from killing the crocodiles at such ecologically lachrymal stage. Consistent creation of awareness against killing of crocodiles at juvenile and sub adult stages, and the use of local legislation can effectively reduce the high rate of crocodile killing at the immature stages. Professional hunters know the locations to set their traps to catch only adults and by that means, tactically avoid killing the juveniles. Since the juveniles were only killed by fishermen through entanglement in fishing nets it implies that their killing can be avoided by setting nets where juveniles cannot stray to. Killing of juveniles is wasteful because it has a lower economic value than the adults even though it is always consumed by the fishing household. The utilization of natural resources such as the Nile crocodile for various purposes by man is not abysmal but when immense pressure is consistently mounted on resources they continue to decrease in number and may eventually become locally extinct.

\section{REFERENCES}

Aust PW 2009 The ecology, conservation and management of Nile crocodiles Crocodylus niloticus in a human dominated landscape. PhD Thesis, Imperial College London.

Bishop JM, Leslie AJ, Bourquin SL and O'Ryan, C 2009 Reduced effective population size in an overexploited population of the Nile crocodile (Crocodylus niloticus). Journal of Biological Conservation 42: 32-39

Bolton M 1997 Conservation and the Use of Wildlife Resources, Chapman and Hall, London.

Broadley DG and Cotterill FPD 2004 The reptiles of southeast Katanga: an overlooked 'hot spot'. African Journal of Herpetology 53: 35-61.

Fergusson RA 2010 Nile Crocodile Crocodylus niloticus Status Survey and Conservation Action Plan. Proceedings of the 11th Working Meeting of the IUCN-SSC Crocodile Specialist Group. IUCN: Gland October $15^{\text {th }} 2010$ Switzerland Pp. 84-89

Harcourt D 2009 Solving Crocodile Shortage in Nigeria with Crocodile Farming, http:// www.ecolocalizer.com 28/06/2010

Hutton J 1989 Movements, home range, dispersal and the separation of size classes in Nile Crocodiles, Journal of American Zoologist 29: 10331049.

Ijeomah HM 2007 Impact of Tourism on Perceived Poverty alleviation in Plateau State, Nigeria. Ph.D Thesis, Department of Wildlife and Fisheries Management, University of Ibadan, Nigeria.301p.

Ijeomah HM and Emelue GU 2009 Ecotourism management and sustainable utilization of Biodiversity in Pandam wildlife park, Nigeria, Journal of Sustainable Development in Africa, 11: 206-222, Clarion, United States of America.

Jones, S. (1991). Crocodiles decline in West Africa. Crocodile Specialist Group Newsletter 10(2): 78.

Lainez D 2009 Nile crocodile survey database, WCMC Cambridge.

Nwankwo CN and Ehirim CN 2010 Evaluation of aquifer characteristics and groundwater quality using Geoelectric Method in Choba, Port Harcourt. Journal of Scholars Research Library 2 :396-403. http://scholarsresearchlibrary.com $28 / 07 / 2010$

Ogogo AU 2008 Wildlife Management in Nigeria, Median, Calabar. Cross River State, Nigeria

Wikipedia 2007 Nile crocodile, http:// en.wikipedia.org/wiki/nilecrocodile\#p, trieved September 16, 2010. 